Prawne i ekonomiczne aspekty imigracji do Polski, red. Magdalena Butrymowicz,

Piotr Kroczek, Kraków 2017, s. 23-40 (Biblioteczka Prawa, 2).

DoI: http://dx.doi.org/10.15633/9788374386340.03

Małgorzata Ćwiek, Paweł Ulman

UNIWERSYTET EKONOMICZNY W KRAKOWIE

\title{
Imigracja do Polski w świetle danych statystycznych
}

W ostatnich latach Europa doświadcza wzmożonego napływu imigrantów. W związku z niewypracowaniem przez Unię Europejską jednolitej polityki migracyjnej poszczególne państwa członkowskie przyjęły nieraz całkiem różne strategie co do przyjmowania imigrantów na własne terytorium. Przykładem całkowitego otwarcia się na imigrantów (przynajmniej do 2016 roku) są Niemcy, które w 2015 roku zarejestrowały nieco mniej niż $2 \mathrm{mln}$ imigrantów. W tym samym czasie ok. 860 tys. zagranicznych obywateli zostało z Niemiec deportowanych, co w konsekwencji dało 1,14 mln imigrantów netto. W Niemczech na koniec 2015 roku żyło 9,1 mln osób przybyłych z zagranicy, a 17,1 mln miało korzenie (doświadczenie) migracyjne ${ }^{1}$. Odmienne podejście reprezentuje Polska, która nie odmawia

1 Podaję za: Federal Statistical Office, https://www.destatis.de/En/FactsFigures/ SocietyState/Population/MigrationIntegration/MigrationIntegration.html (26.10.2017). 
przyjmowania uchodźców, jednak nie godzi się na bezkrytyczne i przymusowe przyjmowanie migrantów, zwłaszcza z krajów obcokulturowych. Ten sprzeciw zbiega się fortunnie z tym, że Polska najczęściej nie jest celem migracji, zwłaszcza tych ekonomicznych, osób przybywających do Europy z południa. Jednak - jak pokazują dane Polska przyjmuje wiele osób przybywających ze wschodu, czego często nie bierze się pod uwagę w dyskusjach na forum europejskim.

W związku z dużym napływem imigrantów do krajów Unii Europejskiej i innych państw o wysokim poziome rozwoju społeczno-gospodarczego w literaturze przedmiotu rozważa się różnorakie skutki tego procesu. Poza wpływem imigrantów na kulturę kraju przyjmującego i problemami z ich asymilacją dużo uwagi poświęca się oddziaływaniu imigrantów na system społeczno-ekonomiczny tego państwa. Przykładowo Giovanni Peri² przedstawia problematykę wpływu imigrantów na rynek pracy państwa przyjmującego przy założeniu różnej polityki imigracyjnej. Z kolei Christian Dustmann, Tommaso Frattini i Ian Preston ${ }^{3}$ podjęli rozważania na temat efektu imigracji na kształtowanie się rozkładu płac rodzimych pracowników. Juan Lacomba i Francisco Lagos ${ }^{4}$ przedstawili wyniki badań nad znaczeniem słabo wykwalifikowanych imigrantów na poziom świadczeń emerytalnych w społeczeństwie przyjmującym. Pokazali oni, że większość kohort ludności w społeczeństwie przyjmującym zyskuje na imigracji w zakresie świadczeń emerytalnych. Jedynie kohorta młodych rodzimych pracowników może czuć się zagrożona z powodu konkurencji w zakresie dostępu i korzystania ze świadczeń emerytalnych w okresie

2 Zob. G. Peri, Immigrants, Productivity, and Labor Markets, „Journal of Economic Perspectives" 30 (2016) no. 4, s. 3-30.

3 Zob. Ch. Dustmann, T. Frattini, I. Preston, The Effect of Immigration along the Distribution of Wages, „The Review of Economic Studies” 80 (2013), s. 145-173.

4 Zob. J. A. Lacomba, F. Lagos, Immigration and Pension Benefits in the Host Country, „Economia” 77 (2010) no. 306, s. 283-295. 
osiągnięcia przez tych pracowników wieku emerytalnego. Do rozważań nad zyskiem netto z przyjmowania imigrantów Masatoshi Jinno ${ }^{5}$ włączył koszty asymilacji. Wskazał on, że zysk netto dla społeczeństwa goszczącego imigrantów wcale nie musi być dodatni: wzrasta wraz ze zwiększaniem się imigracji i spada wraz z wzrastającymi kosztami asymilacji. Przy niskich kosztach asymilacji przyjmowanie imigrantów może być korzystne zarówno dla nich samych, jak i dla rodzimych obywateli państwa przyjmującego. Na tej bazie wskazanym wydaje się krytyczne rozważenie - również od strony ekonomicznej - przyjmowania imigrantów z krajów o odmiennej kulturze.

Celem opracowania jest przedstawienie zakresu i struktury migracji do Polski oraz obecności imigrantów na rynku pracy. Dla realizacji tego celu wykorzystane zostały dane publikowane przez Urząd ds. Cudzoziemców oraz Ministerstwo Rodziny, Pracy i Polityki Społecznej.

\section{Uwagi definicyjne}

Definiowanie zjawisk społecznych, w tym demograficznych, jest zazwyczaj trudne z uwagi na ich dynamiczny charakter oraz częstą niemożność uchwycenia $\mathrm{w}$ pełni istoty problemu wynikającą $\mathrm{z}$ jego różnorodności i złożoności. W przypadku zjawisk społecznych definiuje się je na potrzeby praktyki badań statystycznych albo rozstrzygnięć prawnych. W tym pierwszym przypadku celem jest poznanie stanu rzeczy (poziomu i struktury badanego zjawiska), w tym drugim - kwalifikacji tego, czy dany problem zaistniał, czy nie, co wiąże się z przyznaniem lub odmową danej jednostce praw określonych w przepisach. Często te dwa rodzaje definicji nie są w pełni tożsame, co skutkuje niejednakowym obrazem statystycznym badanego

5 Zob. M. Jinno, Assimilation, Immigration, and the Welfare State, „Public Finance Analysis" 61 (2011) no. 1, s. 46-63. 
zjawiska. Przykładem takich odmienności jest pomiar bezrobocia według BAEL ${ }^{6}$ oraz bezrobocia rejestrowanego lub pomiar liczby osób niepełnosprawnych prawnie lub biologicznie. W związku z powyższym ważnym aspektem prezentacji danych statystycznych dotyczących danego zjawiska jest przedstawienie, jak się je rozumie.

Definicja imigracji (imigranta) stosowana w praktyce badań statystycznych przeprowadzanych przez Główny Urząd Statystyczny (dalej: GUS) jest pochodną definicji rekomendowanej przez Organizację Narodów Zjednoczonych (dalej: oNz), określającą jako długoterminowego migranta osobę, która przeniosła się do państwa innego niż państwo swojego zwykłego pobytu na okres co najmniej 12 miesięcy; tak więc państwo przyjmujące tę osobę staje się krajem jej zwykłego pobytu. Z perspektywy kraju opuszczanego taka osoba jest długoterminowym emigrantem, natomiast z punktu widzenia państwa przyjmującego długoterminowym imigrantem. Jeśli dana osoba opuszcza kraj zwykłego pobytu na dłużej niż 3 miesiące, ale krócej niż rok, i jednocześnie ów wyjazd nie jest motywowany rekreacją, wakacjami, wizytą u przyjaciół lub krewnych, sprawami zawodowymi, leczeniem lub pielgrzymką, to taka osoba jest uważana za emigranta/imigranta krótkookresowego ${ }^{7}$. Ostatecznie więc Gus definiuje imigrację jako przyjazdy z zagranicy w celu osiedlenia się (zamieszkania na stałe) lub na pobyt czasowy ${ }^{8}$.

Na potrzeby polityki migracyjnej Unii Europejskiej imigrację rozumie się jako działanie, w wyniku którego osoba ustanawia swoje miejsce zamieszkania na terytorium państwa członkowskiego na okres,

6 Badanie Aktywności Ekonomicznej Ludności.

7 Zob. Department of Economic and Social Affairs, Recommendations on Statistics of International Migration. Revision 1, „Statistical Papers” series M (1998) no. 58 (New York).

8 Zob. Główny Urząd Statystyczny, Imigracja, w: Słownik pojęć, http://stat. gov.pl/metainformacje/slownik-pojec/pojecia-stosowane-w-statystyce-publicznej/117,pojecie.html (26.10.2017). 
który wynosi co najmniej 12 miesięcy lub co do którego przewiduje się, że będzie on tyle wynosić, będąc uprzednio rezydentem innego państwa członkowskiego lub państwa trzeciego'.

Podstawową przyczyną migracji jest chęć poprawy jakości swojego życia, znalezienia lepszej pracy, szkoły lub dołączenie do członków rodziny. Powyższe definicje migracji teoretycznie nie wykluczają innej ważnej przyczyny przemieszczania się ludności, jaką jest uchodźctwo. Jednak wyodrębnienie tej kategorii osób przemieszczających się między państwami jest ważne dla ich ochrony prawnej i praw socjalnych, które niekoniecznie przysługują imigrantom. Istotnym kryterium rozróżniającym te dwie grupy osób jest dobrowolność procesu przemieszczania się, która zasadniczo dotyczy migrantów, natomiast w przypadku uchodźców wiąże się z przymusowym opuszczeniem swojego miejsca zamieszkania z obawy przed prześladowaniami. W związku z tym, że uchodźctwo wyraźnie różni się od migracji wynikającej z chęci poprawy jakości życia, termin „uchodźca”, jak również prawa przysługujące uchodźcom zostały określone w przepisach międzynarodowych.

W prawie międzynarodowym termin „uchodźca” definiowany jest przez tzw. konwencję genewską z $1951 \mathrm{roku}^{10}$, zmienioną następnie tzw. protokołem nowojorskim z roku $1967^{11}$. Dokumenty te mówią, iż uchodźcą jest osoba, która żywi uzasadnioną obawę przed prześladowaniem z powodu swojej rasy, religii, narodowości, przynależności do określonej grupy społecznej lub poglądów politycznych, znajduje

9 Rozporządzenie (wE) nr 862/2007 Parlamentu Europejskiego i Rady z dnia 11 lipca 2007 r. w sprawie statystyk Wspólnoty z zakresu migracji i ochrony międzynarodowej.

10 Konwencja dotycząca statusu uchodźców, sporządzona w Genewie dnia 28 lipca 1951 r., Dz.U. z 1991 r. Nr 119, poz. 515, dalej: konwencja genewska.

11 Protokół dotyczący statusu uchodźców, sporządzony w Nowym Jorku dnia 31 stycznia 1967 r., Dz.U. 1991 r. Nr 119, poz. 517. 
się poza terytorium kraju, którego jest obywatelem i - z powodu tych obaw - nie chce lub nie może do tego kraju powrócić. Konwencja genewska zawiera również okoliczności, w których cudzoziemiec nie otrzyma statusu uchodźcy lub nadaną ochronę może utracić. Dochodzi do tego, gdy dana osoba: ${ }^{12}$

- popełniła przed przyjazdem do państwa ochrony zbrodnie przeciwko pokojowi, zbrodnie wojenne, zbrodnie przeciwko ludzkości lub poważną zbrodnię o charakterze niepolitycznym,

- dopuściła się czynów sprzecznych z celami i zasadami narodów zjednoczonych,

- aktualnie korzysta z pomocy lub ochrony innych organów lub agencji onz (w tym przybywa $\mathrm{z}$ bezpiecznego kraju trzeciego, który zapewnia jej dostęp do postępowania o nadanie statusu uchodźcy lub status uchodźcy został jej już nadany w innym kraju).

Warto jeszcze raz podkreślić, że status uchodźcy wiąże się z ochroną prawną oraz minimum praw socjalnych. Uchodźca może wystąpić z wnioskiem o azyl i nie może być deportowany do kraju pochodzenia. W przypadku imigrantów każde państwo ma własne odrębne przepisy i procedury, więc zakres ochrony tej grupy osób może być różny w różnych państwach.

\section{Zakres imigracji do Polski}

Zgodnie z ustawą z dnia 12 grudnia 2013 r. o cudzoziemcach ${ }^{13} \mathrm{cu}-$ dzoziemiec może przebywać na terytorium Rzeczpospolitej Polskiej na podstawie:

Na temat procedur przyznawania statusu uchodźcy w Polsce zob. D. Sowińska, Geneza wprowadzenia przepisów regulujących formy ochrony cudzoziemców na terytorium RP, „Przegląd Bezpieczeństwa Wewnętrznego” 4 (2012) nr 6, s. 24-43.

13 Ustawa z dnia 12 grudnia 2013 r. o cudzoziemcach, Dz.U. z 2016 r., poz. 1990 z późn. zm., dalej: ustawa o cudzoziemcach, u.c. 
- wizy,

- zezwolenia na pobyt czasowy (związany z zatrudnieniem, prowadzeniem badań naukowych, prowadzeniem działalności gospodarczej lub studiami, ewentualnie z powodu bycia członkiem rodziny obywatela $\mathrm{RP}$ lub ze względu na inne okoliczności),

- zezwolenia na pobyt stały,

- zezwolenia na pobyt rezydenta długoterminowego Unii Europejskiej.

Według Urzędu ds. Cudzoziemców w połowie 2016 roku zezwolenie na pobyt w Polsce miało 234613 cudzoziemców, co stanowi ok. 0,5 proc. ludności kraju. Prawie połowa cudzoziemców (47 proc.) legalnie przebywających na terytorium Polski mieszka na terenie województwa mazowieckiego. Imigranci często wybierają także województwo dolnośląskie ( 8,26 proc.) i małopolskie $(8,16 \text { proc. })^{14}$.

W ciągu ostatnich trzech lat liczba cudzoziemców, którzy posiadają ważne dokumenty uprawniające do pobytu w Polsce, wzrosła o 60 proc. - z niespełna 150 tys. w 2013 roku do prawie $235 \mathrm{w}$ roku 2016 (por. rysunek 1).

Najwięcej osób przebywających legalnie na terytorium RP posiada zgodę na pobyt czasowy (41 proc.). 29 proc. obcokrajowców to obywatele Unii Europejskiej, którzy zarejestrowali swój pobyt. Kolejne 28 proc. imigrantów ma pozwolenie na pobyt stały. Pozostałe osoby są objęte azylem, posiadają status uchodźcy, mają zgodę na pobyt tolerowany lub udzielono im ochrony uzupełniającej.

Wśród cudzoziemców legalnie przebywających na terytorium RP prawie jedną trzecią stanowią Ukraińcy. Drugą pod względem liczności grupę stanowią Niemcy (10 proc.). Liczną grupę stanowią także Białorusini, Rosjanie, Wietnamczycy, Włosi, Chińczycy, Francuzi,

14 Urząd ds. Cudzoziemców, stan na 1.01.2016, https://udsc.gov.pl/statystyki (20.01.2017). 
Rysunek 1. Liczba osób, które posiadały ważne dokumenty potwierdzające prawo pobytu na terytorium RP - stan na 1 lipca (lata 2013-2016).

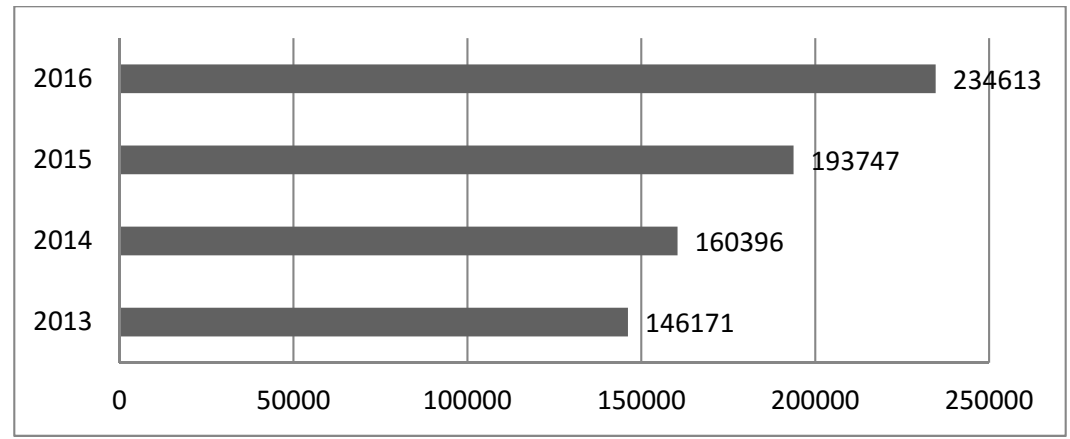

Źródło: opracowanie własne na podstawie danych publikowanych przez Urząd ds. Cudzoziemców

Rysunek 2. Liczba osób legalnie przebywających na terytorium RP według obywatelstwa (stan na 1 stycznia 2016 roku).

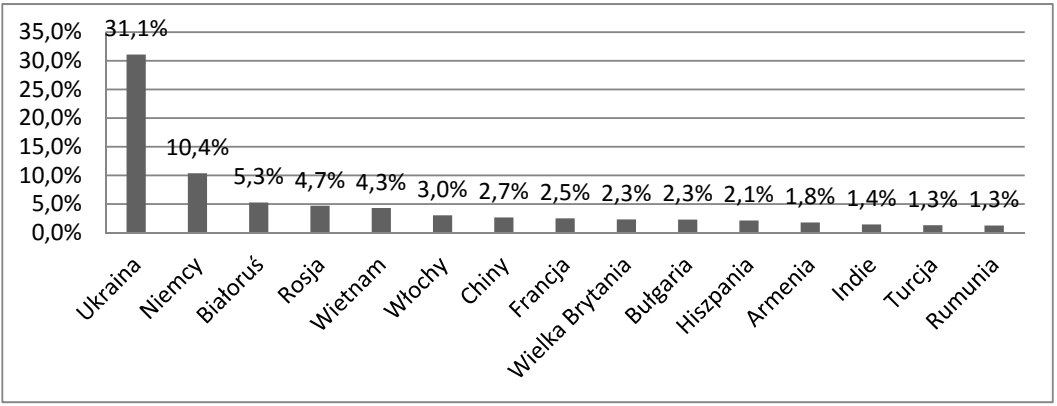

Źródło: opracowanie własne na podstawie danych publikowanych przez Urząd ds. Cudzoziemców

Anglicy, Bułgarzy i Hiszpanie. Obywatele innych państw stanowią mniej niż 2 proc. cudzoziemców w Polsce (por. rysunek 2).

Struktura imigrantów według narodowości jest zróżnicowana ze względu na województwa. Na przykład w województwie małopolskim ponad połowę imigrantów stanowią Ukraińcy. W porównaniu do 
Rysunek 3. Liczba osób legalnie przebywających na terytorium RP według statusu i kraju pochodzenia (stan na 1 stycznia 2016 roku).

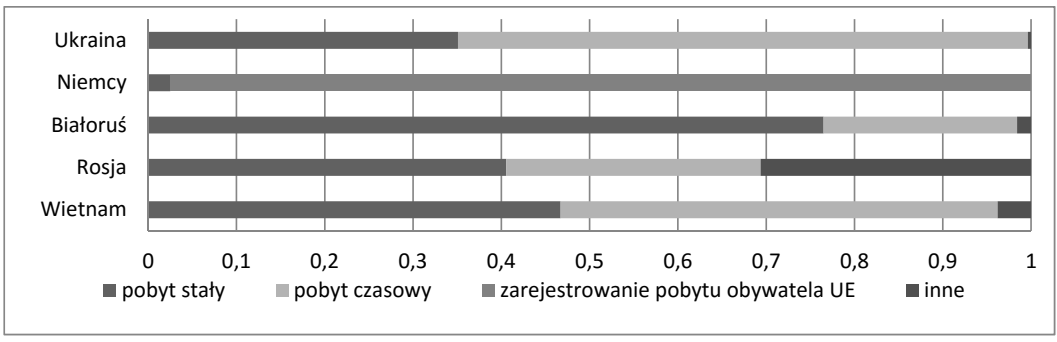

Źródło: opracowanie własne na podstawie danych publikowanych przez Urząd ds. Cudzoziemców

całej Polski w Małopolsce większy odsetek stanowią Włosi (6 proc.), Francuzi (5 proc.), Brytyjczycy (5 proc.), Hiszpanie (4 proc.), obywatele Stanów Zjednoczonych (3 proc.), Słowacy (3 proc.) i Austriacy (2 proc.). Mniejszy jest natomiast odsetek Niemców (5 proc.), Wietnamczyków (2 proc.) oraz Białorusinów (3 proc.).

Obywatele poszczególnych państw różnią się ze względu na status prawny przebywania na terytorium RP. Wśród pięciu najliczniejszych grup narodowościowych w Polsce największy odsetek osób posiadających zgodę na pobyt stały jest wśród Białorusinów (76 proc.) i Wietnamczyków (47 proc.) (por. rysunek 3). W grupie Rosjan pozwolenie na pobyt stały ma 41 proc. osób, wśród Ukraińców 35 proc., natomiast wśród Niemców tylko 3 proc. 97 proc. Niemców przebywa w Polsce na podstawie zarejestrowanego pobytu obywatela Unii Europejskiej. Najwięcej imigrantów z pozwoleniem na pobyt czasowy jest wśród Ukraińców (65 proc.) i Wietnamczyków (50 proc.). Najwięcej osób legitymujących się innym statusem przebywania na terytorium RP (azyl, status uchodźcy, pobyt tolerowany i ochrona uzupełniająca) jest wśród Rosjan (31 proc.). Kategoria „inne” dotyczy także 4 proc. Wietnamczyków i 1,5 proc. Białorusinów przebywających w Polsce. 
Rysunek 4. Liczba wniosków oraz osób objętych wnioskami w sprawach o udzielenie ochrony międzynarodowej w RP W 2015 roku.

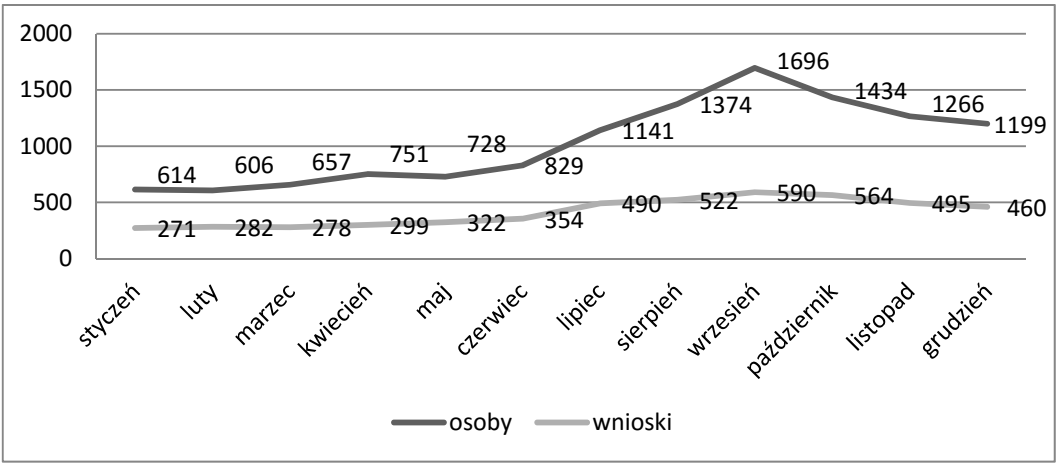

Źródło: opracowanie własne na podstawie danych publikowanych przez Urząd ds. Cudzoziemców

Polska w porównaniu do innych krajów członkowskich Unii Europejskiej plasuje się na 13-14 pozycji pod względem liczby osób ubiegających się o ochronę międzynarodową ${ }^{15}$. Przez pierwsze sześć miesięcy 2015 roku złożono 1806 wniosków o udzielenie ochrony międzynarodowej na terytorium RP. Wnioskami objętych było 4185 osób - o 11 proc. więcej niż w pierwszym półroczu 2014 roku. Ponad połowę wniosków złożyli Rosjanie (z czego 91 proc. narodowości czeczeńskiej). 78 proc. potencjalnych uchodźców złożyło wnioski po raz pierwszy ${ }^{16}$. W drugim półroczu 2015 roku złożono o 73 proc. wniosków więcej, a liczba osób objętych wnioskami wzrosła o 90 proc. w stosunku do pierwszego półrocza i wynosiła 8110 (rysunek 4).

15 Zob. Główne trendy migracyjne - I połowa 2015 roku, http://udsc.gov.pl/wp-content/uploads/2014/12/Komentarz-do-danych-dotycz\%C4\%85cych-zestawienia-za-pierwsze-p\% $\mathrm{C}_{3} \% \mathrm{~B}_{3} \% \mathrm{C}_{5} \% 82$ rocze-2015-roku.pdf (20.01.2017).

Zob. Główne trendy migracyjne..., dz. cyt., s. 2. 
Rysunek 5. Liczba osób, które posiadają status uchodźcy, według obywatelstwa (stan na 1 stycznia 2016 roku).

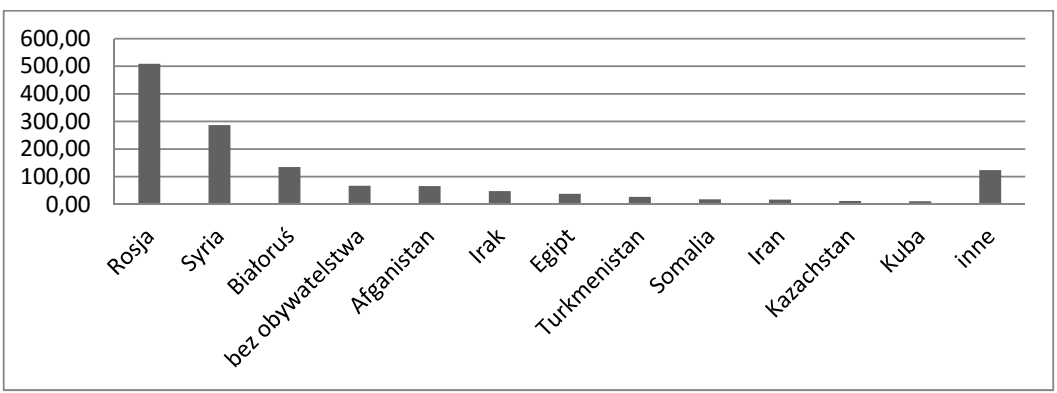

Źródło: opracowanie własne na podstawie danych publikowanych przez Urząd ds. $\mathrm{Cu}-$ dzoziemców

W wyniku rozpatrzenia wniosków w 2015 roku 350 osób uzyskało status uchodźcy, 168 osobom udzielono ochrony uzupełniającej a 110 osób uzyskało zgodę na pobyt tolerowany. Najwięcej decyzji o otrzymaniu statusu uchodźcy w 2015 roku uzyskali obywatele Syrii (58 proc.), Iraku (7 proc.), Rosji (6 proc.) i Egiptu (4 proc.). Kolejne 4 proc. uchodźców to osoby bez obywatelstwa.

Ochrony uzupełniającej w 2015 roku udzielono m.in. obywatelom Rosji (62 proc.), Iraku (14 proc.), Erytrei (6 proc.), Ukrainy (4 proc.) i Afganistanu (4 proc.).

Zdecydowana większość osób, którym wydano zgodę na pobyt tolerowany, to Rosjanie ( 83 proc.). Wśród innych obywateli z tym rodzajem ochrony znaleźli się obywatele Gruzji (6 proc.), Armenii (6 proc.), Turcji (2 proc.), Ukrainy (2 proc.) i Gwinei (2 proc.).

Wśród osób, które posiadają azyl w Polsce, najwięcej jest Rosjan (509 osób), Syryjczyków (287), Białorusinów (135), Afgańczyków (66), Irakijczyków (48) i Egipcjan (38) (por. rys. 5). Sporą grupę stanowią także tzw. bezpaństwowcy, czyli osoby nieposiadające żadnego obywatelstwa (67). Ogółem 1 stycznia 2016 roku w Polsce 1359 osób posiadało status uchodźcy. 


\section{Imigranci na rynku pracy w Polsce}

Szczególnie dużym zainteresowaniem wśród cudzoziemców przybywających do Polski cieszy się imigracja zarobkowa - dwie trzecie wniosków o pobyt czasowy złożonych w 2016 roku uzasadnionych było chęcią podjęcia pracy ${ }^{17}$. Najistotniejszymi aktami prawnymi regulującymi zasady powierzania pracy cudzoziemcom w Polsce są:

- ustawa z dnia 20 kwietnia 2004 r. o promocji zatrudnienia i instytucjach rynku pracy ${ }^{18}$,

- Rozporządzenie Ministra Pracy i Polityki Społecznej z dnia 29 stycznia 2009 r. w sprawie wydawania zezwolenia na pracę cudzoziemców ${ }^{19}$,

- Rozporządzenia Ministra Pracy i Polityki Społecznej z dnia 29 stycznia 2009 r. w sprawie określenia przypadków, w których zezwolenie na pracę cudzoziemca jest wydawane bez względu na szczegółowe warunki wydawania zezwoleń na pracę cudzoziemców ${ }^{20}$,

- Rozporządzenie Ministra Pracy i Polityki Społecznej z dnia 20 lipca $2011 \mathrm{r}$. w sprawie przypadków, w których powierzenie wykonywania pracy cudzoziemcowi na terytorium Rzeczypospolitej Polskiej jest dopuszczalne bez konieczności uzyskiwania pozwolenia na pracę ${ }^{21}$.

17 Zob. Urząd ds. Cudzoziemców, Raport na temat obywateli Ukrainy. Warszawa, stan na 15 stycznia 2017 roku, https://udsc.gov.pl/wp-content/uploads/2014/12/ Ukraina-15.01.2017.pdf (20.01.2017), s. 8. 
W świetle polskiego prawa, z punktu widzenia dostępu do rynku pracy w Polsce, można wskazać trzy kategorie imigrantów ${ }^{22}$ :

- osoby posiadające swobodny dostępu do rynku pracy w Polsce,

- osoby uprawnione do podejmowania pracy w Polsce na podstawie zezwolenia na pracę,

- osoby uprawnione do podejmowania pracy na podstawie oświadczenia pracodawcy o zamiarze powierzenia pracy cudzoziemcowi.

Do pracy na terytorium RP bez konieczności uzyskiwania zezwolenia na pracę uprawnieni są między innymi: niektórzy cudzoziemcy posiadający zezwolenie na pobyt czasowy $\mathrm{w}$ RP, osoby posiadające ważną Kartę Polaka, osoby ubiegające się o nadanie statusu uchodźcy, osoby uprawnione do przebywania i wykonywania pracy na terytorium Europejskiego Obszaru Gospodarczego lub Konfederacji Szwajcarii, a także nauczyciele języków obcych, nauczyciele akademiccy, korespondenci zagraniczni środków masowego przekazu, sportowcy, artyści, duchowni wykonujący pracę w związku z pełnioną funkcją religijną, członkowie sił zbrojnych lub personelu cywilnego wykonujący pracę $\mathrm{w}$ międzynarodowych strukturach wojskowych na terytorium RP, pracownicy delegowani na okres nieprzekraczający trzech miesięcy, a także osoby wykonujące pracę na rzecz posłów do Parlamentu Europejskiego $^{23}$.

Imigranci będący obywatelami Białorusi, Gruzji, Mołdawii, Rosji, Ukrainy oraz Armenii, wykonujący pracę przez okres nieprzekraczający sześciu miesięcy w ciągu kolejnych dwunastu miesięcy mogą podejmować pracę na terytorium RP bez ubiegania się o pozwolenie

22 Zob. M. Piotrowski, A. Organiściak-Krzykowska, Rola cudzoziemców na rynku pracy w Polsce, „Studia Prawno-Ekonomiczne” XCIII (2014), s. 264.

23 Zob. M. Piotrowski, A. Organiściak-Krzykowska, Rola cudzoziemców..., dz. cyt., s. $264-265$. 
na pracę, jeżeli przed jej podjęciem pracodawca złożył pisemne oświadczenie o zamiarze powierzenia wykonywania pracy cudzoziemcowi ${ }^{24}$.

Zainteresowanie pracą znajduje odbicie w liczbie wydawanych zezwoleń na pracę. W latach 2010-2015 liczba wydanych pozwoleń na pracę wzrosła o 80 proc. i w 2015 roku wynosiła 65786 (por. rysunek 6).

Rysunek 6. Liczba zezwoleń na pracę wydanych w latach 2010-2015.

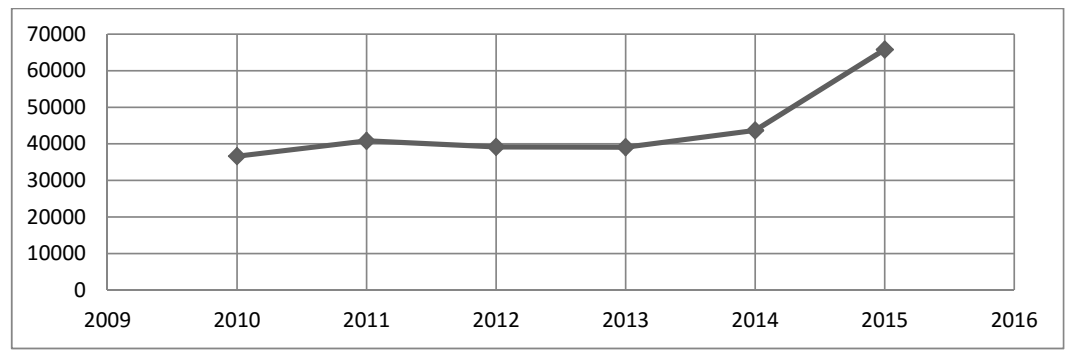

Źródło: opracowanie własne na podstawie: Informacja nt. zatrudniania... ${ }^{25}$

Ponad trzy czwarte zezwoleń na pracę wydanych przez cudzoziemców w 2015 roku zostało przyznanych Ukraińcom (por. rysunek 7). Kolejne miejsca w strukturze wydawanych zezwoleń według obywatelstwa zajmują: obywatele Białorusi (3,09 proc.), Mołdawii (2,26 proc.),

24 Rozporządzenie Ministra Pracy i Polityki Społecznej z dnia 28 listopada 2013 r. zmieniające rozporządzenie w sprawie przypadków, w których powierzenie wykonywania pracy cudzoziemcowi na terytorium Rzeczypospolitej Polskiej jest dopuszczalne bez konieczności uzyskania zezwolenia na pracę, Dz.U. z 2013 r., poz. 1507.

Zob. Ministerstwo Rodziny, Pracy i Polityki Społecznej, Informacja nt. zatrudniania cudzoziemców w Polsce (grudzień 2016), https://www.mpips.gov.pl/gfx/ mpips/userfiles/_public/1_NOWA\%2OSTRONA/Analizy\%20i\%2oraporty/cudzoziemncy\%2opracujacy\%20w\%2opolsce/zatrudnianie\%2ocudzoziemcow\%202016. $\operatorname{pdf}(27.10 .2017)$. 
Uzbekistanu (2,18 proc.), Indii (2,17 proc.), Chin (1,97 proc.) i Wietnamu (1,11 proc.).

Rysunek 7. Zezwolenia na pracę dla imigrantów wydane w 2015 roku według obywatelstwa.

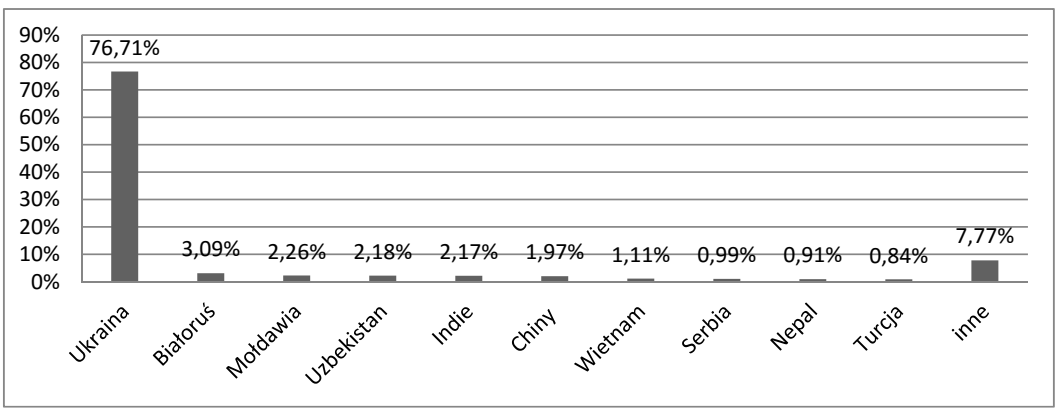

Źródło: opracowanie własne na podstawie: Informacja $n t$. zatrudniania...

Najwięcej zezwoleń na pracę dla cudzoziemców wydawanych jest $\mathrm{w}$ budownictwie ( $\mathrm{w} 2015$ roku prawie 20 proc.). W ostatnich latach widoczny jest spadek udziału zezwoleń na pracę wydawanych w handlu (z 18 proc. w 2012 do 8 proc. w 2015) i działalności związanej z zakwaterowaniem i usługami gastronomicznymi (spadek o 50 proc. w 2015 roku w porównaniu do roku 2012). Wzrósł natomiast udział zezwoleń na pracę wydawanych w transporcie i gospodarce magazynowej.

Tabela 1. Udział procentowy wybranych sekcji $\mathrm{PKD}^{26} \mathrm{~W}$ ogólnej liczbie wydanych zezwoleń

\begin{tabular}{|c|c|c|c|c|}
\hline sekcja PKD & 2012 & 2013 & 2014 & 2015 \\
\hline rolnictwo, leśnictwo, lowiectwo i rybactwo & $4,40 \%$ & $4,70 \%$ & $5,30 \%$ & $4,80 \%$ \\
\hline przetwórstwo przemysłowe & $6,20 \%$ & $4,80 \%$ & $4,90 \%$ & $6,90 \%$ \\
\hline
\end{tabular}

26 Polska Klasyfikacja Działalności. 


\begin{tabular}{|c|c|c|c|c|}
\hline sekcja PKD & 2012 & 2013 & 2014 & 2015 \\
\hline budownictwo & $19,80 \%$ & $12,90 \%$ & $16,20 \%$ & $19,60 \%$ \\
\hline handel hurtowy i detaliczny & $17,80 \%$ & $18,30 \%$ & $15,10 \%$ & $8,40 \%$ \\
\hline $\begin{array}{c}\text { transport i gospodarka magazynowa } \\
\text { działalność związana z zakwaterowaniem } \\
\text { i usługami gastronomicznymi }\end{array}$ & $7,80 \%$ & $8,60 \%$ & $9,80 \%$ & $12,10 \%$ \\
\hline $\begin{array}{c}\text { działalność profesjonalna, naukowa i techniczna } \\
\text { gospodarstwa domowe zatrudniające pracowników }\end{array}$ & $11,40 \%$ & $12,80 \%$ & $13,20 \%$ & $11,50 \%$ \\
\hline
\end{tabular}

Źródło: opracowanie własne na podstawie: Informacja nt. zatrudniania...

Liczba składanych oświadczeń o zamiarze powierzenia pracy cudzoziemcowi w latach 2008-2015 wzrosła, według danych Ministerstwa Rodziny, Pracy i Polityki Społecznej, prawie pięciokrotnie (ze 160 tys. w 2008 roku do niemal 790 tys. w roku 2015). Struktura oświadczeń zarejestrowanych w 2015 roku według obywatelstwa zdominowana jest przez obywateli Ukrainy (97,5 proc.). Nieco ponad jeden procent (1,22 proc.) oświadczeń dotyczy obywateli Mołdawii. Inne obywatelstwa, jak gruzińskie, armeńskie, białoruskie i rosyjskie, stanowią mniej niż 1 proc.

\section{Podsumowanie}

Liczba imigrantów przebywających legalnie w Polsce wynosi obecnie ok. o,5 proc. ludności Polski i stale rośnie. Prawie połowa cudzoziemców zamieszkuje w województwie mazowieckim. Wśród imigrantów największą grupę stanowią Ukraińcy, Niemcy, Białorusini, Rosjanie oraz Wietnamczycy. Ukraińcy i Wietnamczycy w większości mają pozwolenie na pobyt czasowy, Rosjanie i Białorusini na pobyt stały, a Niemcy w większości przebywają w Polsce na podstawie rejestrowanego pobytu obywatela Unii Europejskiej. Wśród osób posiadających status uchodźcy najwięcej jest Rosjan, Białorusinów oraz Syryjczyków. 
Rok 2015 był rekordowy zarówno pod względem liczby wydanych zezwoleń na pracę dla cudzoziemców, jak i zarejestrowanych oświadczeń powierzenia pracy cudzoziemcowi. Dane z początku 2016 roku wskazują na kontynuację trendu wzrostowego.

Rośnie udział obywateli Ukrainy w liczbie wydanych zezwoleń na pracę i zarejestrowanych oświadczeń (obecnie to odpowiednio ok. 77 proc. i niecałe 98 proc.). Najwięcej cudzoziemców pracuje $\mathrm{w}$ budownictwie, transporcie i gospodarce magazynowej oraz w gospodarstwach domowych zatrudniających pracowników.

Imigracja do Polski może odbywać się z korzyścią dla naszego kraju w sytuacji starzejącego się społeczeństwa i wynikającego z tego zmniejszania się zasobu siły roboczej. Już teraz dochodzą do opinii publicznej sygnały, że wiele przedsiębiorstw, zwłaszcza we wschodniej Polsce, miałoby duże trudności z pozyskaniem pracowników, gdyby nie zatrudniało imigrantów przede wszystkim ze wschodu Europy. W związku z wejściem w wiek emerytalny osób urodzonych $\mathrm{z}$ początkiem lat 50. $\mathrm{xx} \mathrm{w}$. (powojenny wyż demograficzny) w polskim społeczeństwie przybędzie ludzi starych. Ten ubytek nie będzie zrekompensowany osobami młodymi wchodzącymi na rynek pracy. Powstanie więc niedobór (w pewnym okresie) siły roboczej nawet przy założeniu rozwoju technologicznego produkcji i usług. $\mathrm{Z}$ tego względu dla rozwoju gospodarczego Polski może okazać się koniecznym zatrudnianie imigrantów. Jednak w tym względzie konieczna jest właściwa polityka maksymalizująca korzyści i minimalizująca zagrożenia wynikające z imigracji do Polski.

\section{Summary}

Immigration to Poland according to statistical data

Immigration as a phenomenon of significant socio-economic effects, requires constant monitoring. The article discusses terminology related to migration movement used by selected national and international institutions. The 
study covers the analysis of scope and structure of migration to Poland by citizenship and legal status of foreigners and situation of immigrants in the labor market. For the analysis, there are used data from Office for Foreigners and Ministry of Family, Labour and Social Policy.

Keywords: immigration, immigration to Poland, immigrants on the labor market in Poland 